\title{
Adult Pancreatic Alpha-Cells: A N ew Source of Cells for Beta-Cell Regeneration
}

\author{
Cheng-Ho Chung ${ }^{1,2,3}$ and Fred Levine ${ }^{1}$ \\ 'Sanford Children's Health Research Center, Sanford-Burnham Medical Research Institute 10901 N. Torrey Pines Road, CA 92037, \\ USA. ${ }^{2}$ Sanford-Burnham Institute Graduate Program. ${ }^{3}$ Mackay Memorial Hospital, Taipei, Taiwan. \\ Address correspondence to: Fred Levine, e-mail: flevine@sanfordburnham.org
}

Manuscript submitted Jul y 9, 2010; resubmitted Jul y 27, 2010; accepted A ugust 9, 2010

\section{- Abstract}

Beta-cell deficit is the major pathological feature in type 1 and type 2 diabetes patients, and plays a key role in disease progression. In principle, beta-cell regeneration can occur by replication of pre-existing beta-cells, or by beta-cell neogenesis from stem/ progenitors. Unfortunately, beta-cell replication is limited by the almost complete absence of beta-cells in patients with type 1 diabetes, and the increasing recognition that the beta-cell replicative capacity declines severely with age. Therefore, beta-cell neogenesis has received increasing interest. $M$ any different cell types within the pancreas have been suggested as potential beta-cell stem/ progenitor cells, but the data have been conflicting. In some cases, this may be due to different regeneration models. On the other hand, different results have been obtained

\section{Overview of adult beta-cell regenera- tion}

here are two ways to create new beta-cells: 1. replication from pre-existing beta-cells, and 2. neogenesis from non-beta cells. The relative contributions of these two processes to the maintenance of beta-cell mass is controversial. In humans, it is unclear whether significant beta-cell regeneration occurs at all [1]. In the mouse, where the overwhelming majority of studies have been performed, the mode of regeneration appears to vary depending on the stimulus for regeneration. with similar regeneration models, leading to confusion about the nature and existence of beta-cell neogenesis in adult animals. Here, we review the major candidates for adult regeneration pathways, and focus on the recent discovery that alpha-cells can function as a novel beta-cell progenitor. Of note, this is a pathway that appears to be unique to beta-cell neogenesis in the adult, as the embryonic pathway of betacell neogenesis does not proceed through a glucagonpositive intermediate. We conclude that beta-cell neogenesis from alpha-cells is a new pathway of potential therapeutic significance, making it of high importance to elucidate the molecular events in alpha- to beta-cell conversion.

Keywords: stem cell - duct - pancreatic duct ligation - betacell - alpha-cell $\cdot$ conversion $\cdot$ insulin $\cdot$ glucagon $\cdot$ genetic lineage tracing $\cdot$ proliferation

This has led to substantial confusion in the field, with conflicting results as to the existence and nature of beta-cell regeneration in adult animals. One consideration is that the degree of plasticity in the adult pancreas is much greater than previously suspected. There is a large number of different cell types within both the exocrine and endocrine pancreas. Several are able to contribute to beta-cell regeneration [1]. The relative contribution of any particular cell type to the ultimate beta-cell mass depends on the stimulus, which can be physiologic (e.g., pregnancy or obesity), or a kind of damage (e.g., duct ligation, beta-cell ablation, or partial pancreatectomy). 


Abbreviations:
BrdU - bromodeoxyuridine or 5-bromo-2-deoxyuridine (ana-
logue of thymidine; used in the detection of proliferating
cells in living tissues)
Cre recombinase - type I topoisomerase (catalyzes site-
specific recombination of DNA between loxP sites)
EGF - epidermal growth factor
IGF-1- insulin-like growth factor 1
IL - interleukin
MafA - v-maf musculoaponeurotic fibrosarcoma oncogene
homolog A (transcription factor necessary for beta-cell
maturation)
MafB - v-maf musculoaponeurotic fibrosarcoma oncogene
homolog B (transcription factor important for alpha- and
beta-cell devel opment and mature alpha-cell function)
mRNA - messenger ribonucleic acid
NF-kappaB - nuclear factor kappa-light-chain-enhancer of
activated B-cells
Nkx6.1 - homeobox protein required for $\beta$-cell development
Pax4 - paired box gene 4 (transcription factor involved in
fetal and pancreas development)
PDL - partial duct ligation
Pdx1 - pancreatic and duodenal homeobox 1 (transcription
factor necessary for pancreas devel opment)
T1D - type 1 diabetes
T2D - type 2 diabetes
TGF-al pha - transforming growth factor al pha

\section{Beta-cell replication}

Beta-cell replication has been studied for a long time. In young adult mice, beta-cell replication can be achieved in several physiological and experimental models, such as obesity, glucose infusion, pregnancy, manipulating growth-hormone expression, and partial pancreatectomy [2-8]. However, murine beta-cell replication declines with age, which restricts the potential for beta-cell regeneration by that route $[9,10]$.

Beta-cell biology in humans seems to be very different from that of mice. It has been reported that human beta-cells are much Ionger-lived than murine beta-cells [11]. The human adult beta-cell population has been largely established by age 20 , and then remains constant thereafter [10], indicating that the turnover of human beta-cells may be rare. A study measuring beta-cell replication used in vivo thymidine analog incorporation and radiocarbon dating. It was found that under typical circumstances, human beta-cells and their cellular precursors are established by young adulthood [12].

It has been difficult to demonstrate replication of human beta-cells in settings where replication of murine beta-cells is well established, e.g. in obesity, type 2 diabetes (T2D) [13], pregnancy [14], and partial pancreatectomy [15]. It has been re- ported that human beta-cells could be induced to proliferate in the presence of hepatocyte growth factor. However, these cells lost insulin expression after approximately five doublings [16, 17]. Also, it was questionable whether the replicating cells were beta-cells or contaminating duct cells [18]. A recent report indicated that human beta-cells could be induced to enter the cell cycle by overexpressing cyclin-dependent kinase 6 [19]. However, it is unclear whether this approach induced proliferation of beta-cells, with consequent increase in beta-cell number or mass in vitro or in vivo, since those parameters were not measured. Finally, whilst some recent studies have found residual beta-cells in some type 1 diabetes (T1D) patients [20], the number of those cells is small. Thus, induction of beta-cell replication is likely to be most effective early in the course of the disease as the number of residual beta-cells remaining later in the disease process are too small to replicate.

\section{Beta-cell neogenesis}

In adults, many cell types within the pancreas have been studied as possible candidates for betacell stem/progenitor cells. These include acinar cells, centroacinar cells, duct cells, and delta-cells [21-26]. Due to the low turnover rate of the betacell population, most of the current evidence available for adult beta-cell neogenesis comes from damage models, disease models, and in vitro culture. Each of these models provides a different set of conditions and potential stimuli that may result in activation of potential stem/progenitor cells [1].

Embryonic insulin-producing cells arise from pancreatic ductal epithelial progenitor cells. For decades, adult pancreatic ductal epithelium has been regarded as the most likely source of betacell progenitors [27-29]. Two findings have provided support for the theory that adult ductal cells could function as beta-cell progenitors: 1. the morphological finding of "insulin-producing cells existing in the duct or near the duct" [27-29], and 2. lineage-tracing experiments using pancreatic ductal ligation as damage model $[24,30]$. In humans, an increase in insulin-positive cells in the ducts has been observed in chronic pancreatitis [31], and in T1D patients receiving simultaneous pancreaskidney transplantation with recurrent autoimmunity [32].

Using genetic lineage tracing, we have shown that human exocrine cells cultured in vitro can be differentiated into beta-cells, under the influence of inductive factors present in the human fetal pancreas. However, the efficiency of this process 

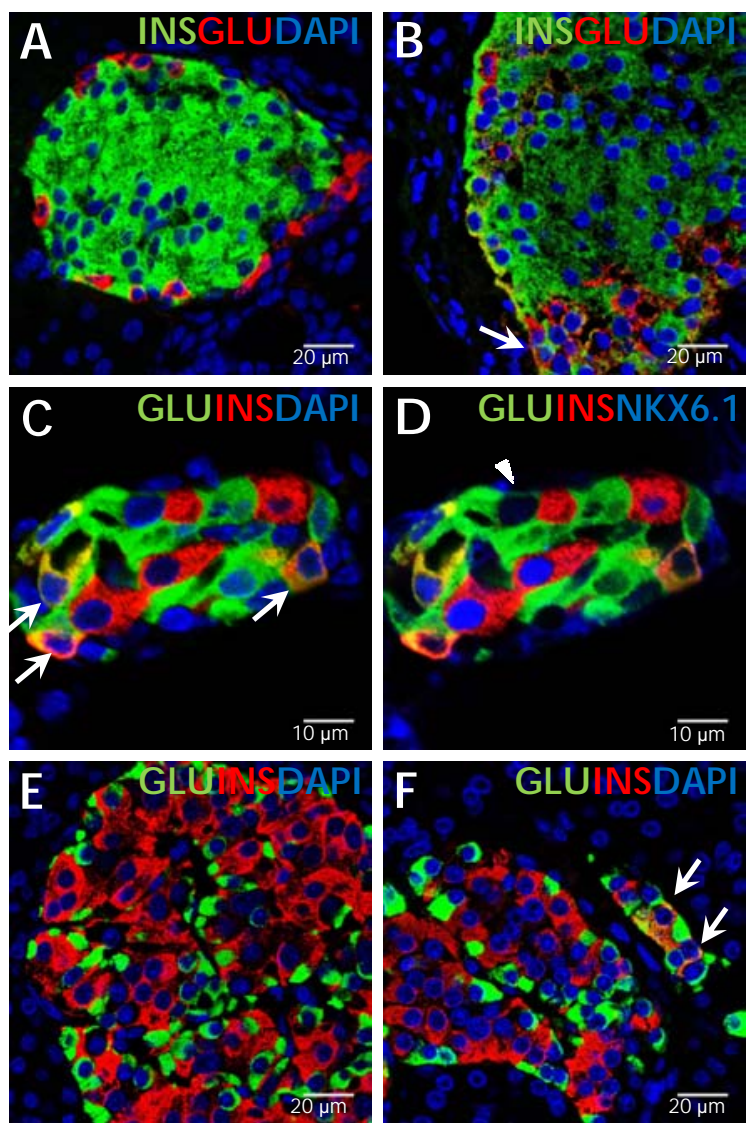

Figure 1. Transitional endocrine cells in mouse and human pancreas. The figure shows representative sections from normal adult mouse pancreas (A), adult mouse pancreas 7 days after pancreatic duct ligation (B), and adult mouse pancreas 14 days after pancreatic duct ligation and alloxan injection (C and $\mathbf{D}$ ). Transitional cells co-expressing insulin and glucagon do not exist in normal adult mouse pancreas (A). A cell co-expressing insulin (green) and glucagon (red) is indicated by the arrow in image $\mathbf{B}$. $\mathbf{C}$ and $\mathbf{D}$ represent the same islet immunostained with antibodies against glucagon (green), insulin (red), and DAPI (blue) (C), or with antibodies against glucagon (green), insulin (red), and NKX6.1 (blue) (D). Numerous cells co-expressing insulin and glucagon also express NKX6.1 (C, indicated by arrows). O nly one alpha-cell expressed low levels of N KX6.1, but not insulin (D, indicated by arrowhead). Representative pancreatic sections from an adult human patient without pancreatitis are shown in $\mathbf{E}$, and from an adult human patient with pancreatitis in $\mathbf{F}$. Endocrine cells in the adult human pancreas do not coexpress insulin (red) and glucagon (green) (E), but such double positive cells were found in patients with pancreatitis $(\mathbf{F}$, indicated by arrows). Scale bar, $10 \mu \mathrm{m}$ (C and D); 20 um (A, B, E, and F).

appeared to be low [33]. In the mouse, a lineage tracing study has been performed using the hu- man carbonic anhydrase II promoter to induce Cre recombinase expression in ductular epithelial cells. It was found that significant beta-cell neogenesis resulted from ductal cells following pancreatic duct ligation (PDL) [30]. However, other studies using the same PDL damage model with different promoters for Cre recombinase induction (hepatocyte nuclear factor 1 beta or neurogenin 3), did not find strong evidence that these adult ductal epithelial cells converted into beta-cells within islets [34]. Although, these studies did find evidence of insulin-positive cell formation within ducts. Hence, adult pancreatic ductal cells appear to be capable of beta-cell differentiation, but the extent of beta-cell neogenesis from ducts is still under debate.

\section{Alpha-cells can serve as a novel source of beta-cell progenitors}

The large number of pre-existing beta-cells in most models is the confounding factor in the study of beta-cell neogenesis. We created a new damage model to better study the origin and extent of adult beta-cell neogenesis in which beta-cellspecific toxin alloxan was invected to eliminate all pre-existing beta-cells. Subsequently, we performed PDL to stimulate beta-cell neogenesis. In this PDL plus alloxan model, virtually all betacells that appeared after treatment were neogenic. To our surprise, we found a large number of new beta-cells arising from adult al pha-cells within 14 days (Figure 1C and 1D). At one week following PDL plus alloxan, $58 \%$ of insulin-positive cells coexpressed glucagon. Whilst beta-cell neogenesis from ducts occurred, as it did in PDL alone; such cells were relatively rare, and could not account for the robust beta-cell neogenesis that was observed.

The process of alpha to beta-cell conversion involved an intermediate cell type, in which glucagon-positive alpha-cells started to express betacell-specific transcription factors such as Pdx1 and Nkx6.1. Subsequently, insulin protein was produced, and cells co-expressing insulin and glucagon appeared (Figure 1C and 1D). Those insulinpositive cells expressed MafB and were initially immature, but became mature over time with MafA instead of MafB expression [35].

Normally, the adult alpha-cell is not highly proliferative, and the major physiological role of the alpha-cell is to secrete glucagon, which plays an important role in glucose homeostasis. In the PDL plus alloxan model, alpha-cells responded to 
environmental cues in a diverse manner. Firstly, they could replicate, which resulted into alpha-cell hyperplasia serving as a potential pool of beta-cell progenitors. Secondly, alpha-cells could differentiate into beta-cells through direct conversion, without intervening replication. Finally, some alphacells replicated first, and then converted to betacells (Figure 2) [33]. control of the insulin promoter. In this model, it took 5-10 months for significant numbers of new beta-cells to form, after which some mice became normoglycemic [38]. In contrast, our model was much more rapid in terms of beta-cell neogenesis, but did not result in reversion to normoglycemia. The latter was possibly due to the persistent profound inflammation and damage caused by the ligation [35]. While the low efficiency of the diphtheria toxin model makes mechanistic studies of alpha- to beta-cell conversion difficult, the reversion to normoglycemia in that model is an important demonstration of the potential for alpha-cells to serve as a clinically relevant source of beta-cell progenitors. Deeper study of both models is needed to clarify the factors mediating the conversion process, and to enable clinical translation.

\section{Signals responsible for alpha- to beta-cell con- version remain un- known}

What happens in the pancreas after PDL plus alloxan?

In the normal pancreas, pancreatic juice secreted by pancreatic acinar and ductal

It is interesting to note that the alpha-cell and beta-cell lineages arise independent during normal ontogeny [36]. Transgenic overexpression of transcription factor Pax4 under the control of the glucagon promoter resulted in a lineage switch from alpha- to beta-cells; but this phenomenon was limited to the embryo, and did not occur in adult animals [37]. Our finding of adult beta-cell neogenesis from adult alpha-cells provides evidence for adult beta-cell neogenesis without recapitulating the pathway of beta-cell neogenesis during development.

Alpha- to beta-cell conversion has been demonstrated independently using a different damage model. In this model, a near-total ablation of preexisting beta-cells was achieved by transgenic expression of the diphtheria toxin receptor under the cells flows through the pancreatic duct into the duodenum. Pancreatic juice is composed mainly of exocrine enzymes and bicarbonate ions, but some growth factors such as epidermal growth factor (EGF) and insulin-like growth factor 1 (IGF-1) are also found there [39, 40]. After PDL, pancreatic juice accumulates due to pancreatic duct blockage. The retained pancreatic juice injures the pancreas, resulting in acinar-cell apoptosis, local inflammation, recruitment of inflammatory response cells attracted by the inflammation, ductal cell hyperplasia, fibrosis, and extensive remodeling of the extracellular environment [24, 41]. PDL induces strong cytokine expression in the pancreas. It has been reported that interleukin-lalpha ( L-1alpha), IL-1beta, IL-1 receptor antagonist, IL-6, IL-10, and tumor-necrosis factor-alpha (TNF-alpha) 
mRNAs were upregulated in the pancreas within 1 to 3 days after PDL, and remained at high levels on day 7 [42]. Other inflammatory mediators, such as platelet-activating factor and substance $P$, and activation of transcriptional factors NF-kappaB and activator protein-1 were also found in similar conditions [43-45]. However, the relative contributions of these potential factors to alpha- to betacell conversion is unknown.

Concurrent with PDL, we eliminated nearly all pre-existing beta-cells with alloxan. Alloxan is a beta-cell-specific toxin that results in rapid betacell death and transient massive insulin release, as a result of toxin-induced secretory granule and cell-membrane rupture [46]. A summary of the PDL plus alloxan model is presented in Figure 2.

Is the near-total loss of beta-cell mass critical for alpha- to beta-cell conversion?

An important question is the extent to which near-total loss of beta-cell mass is a prerequisite for triggering alpha- to beta-cell conversion. It is known that alpha-cell and beta-cell function and growth are highly interrelated [47]. Glucagon secretion is modulated by insulin and zinc secreted by beta-cells [47]. Genetic deletion of al pha-cell insulin receptors results in an increase in beta-cell mass and a decrease in alpha-cell mass [48]. In human islets, cell-cell contacts between al pha- and beta-cells are numerous. It has been reported that the frequency of alpha-beta cell contacts is much higher than the frequency of alpha-alpha cell contacts or beta-beta cell contacts. Also, alpha-cells surrounded by beta-cell extensions, are often observed [49]. The ablation of pre-existing beta-cells eliminates alpha-beta cell contact, but increases cell contacts between alpha-cells and non-betacells. Whether the signaling between alpha- and beta-cells involves direct cell-cell contact, or is mediated by secreted factors, remains to be determined.

So far, alpha- to beta-cell conversion has only been observed in experimental settings with nearcomplete beta-cell ablation [35, 38]. Another experiment, using transgenic mice expressing diphtheria toxin in beta-cells to achieve $70-80 \%$ betacell destruction, did not find evidence for alpha- to beta-cell conversion [50]. Those results lead to a suggestion that near-total beta-cell loss might be a prerequisite, or a promoting factor, for triggering alpha- to beta-cell conversion. However, cells coexpressing insulin and glucagon exist following PDL alone (Figure 1B). In humans, we have found small numbers of cells co-expressing insulin and glucagon in patients with acute pancreatitis (Figure $1 F$ ); but it is not known whether those cells represent a transitional state that will go on to form neogenic mature beta-cells. Nonetheless, the finding of cells co-expressing glucagon and insulin in humans with pancreatitis, raises the hope that one day, beta-cell neogenesis from alpha-cells might be clinically applicable.

\section{Alpha-cell proliferation and alpha- to beta-cel I conversion are independent processes}

Both alpha-cell replication and alpha- to betacell differentiation occurred in the PDL plus alIoxan model. This observation raised the question whether replication and al pha- to beta-cell conversion might be linked. For example, alpha-cells might divide asymmetrically to generate another alpha-cell and a differentiated beta-cell, as in classical models of stem cell biology. We addressed this question using continuous BrdU labeling, and found that al pha- to beta-cell conversion could occur without intervening replication. This finding indicated that alpha-cell replication, and alpha- to beta-cell conversion, are independent processes, and asymmetric division is not required [35]. The finding is also consistent with previous studies of human T2D [51], and glucagon receptor knockout mice [52], in which alpha-cell hyperplasia occurred without concomitant beta-cell neogenesis.

\section{Inflammation may play a role in alpha- to beta-cell conversion}

Currently, the signals triggering al pha- to betacell conversion are not known. In fact, there may be several ways to convert one terminally differentiated cell into another. Some methods involve the use of viral vectors to ectopically express specific transcription factors $[26,53]$. Others are related to tissue damage [54]. It has been proposed that inflammation induced by viral infection may facilitate the cell-conversion process [55, 56]. A similar phenomenon might exist as well in tissue damage models, including the PDL plus alloxan model. Indeed, another significant difference between the two current models of alpha- to beta-cell conversion is that PDL plus alloxan might induce much stronger inflammation than pure beta-cell ablation. Perhaps, this stronger inflammation contributes to the much more rapid kinetics of the conversion in the PDL plus alloxan model compared with mere beta-cell ablation. Given the lack of 
evidence, future study is needed to elucidate the underlying mechanisms of alpha- to beta-cell conversion. This may be the key to a successful clinical translation.

\section{Generating new beta-cells from adult alpha-cells could be a revolutionary approach for diabetes therapy}

Despite remaining open questions about the mechanisms of alpha- to beta-cell conversion, it has been demonstrated that the process occurs and that it can be rapid and robust. We have also learned that it occurs to a significant albeit lesser degree even in older animals [35]. Thus, it is worthwhile to explore its potential as a new therapeutic approach for diabetic patients. Unlike beta-cells, alpha-cells are intact in T1D patients, and they are increased in T2D patients. One important research avenue will be to re-evaluate existing models of beta-cell regeneration for the occurrence of alpha- to beta-cell conversion. When we have built up a sufficiently detailed understanding of the mechanisms, it may be possible to induce alpha- to beta-cell conversion through pharmacology. In the longer term, this could lead to a universal treatment for diabetes.

Acknowledgements: This work was supported by the Sanford Children's Health Research Center, the Mackay Memorial Hospital, and the J.W. Kieckhefer Foundation.

Disclosures (conflict of interests statement): The authors report no conflict of interests.

\section{R eferences}

1. Levine F, Itkin-Ansari P. Beta-cell R egeneration: neogenesis, replication or both? J M ol M ed 2008. 86(3):247-258.

2. Hull RL, Kodama K, Utzschneider KM, Carr DB, Prigeon RL, Kahn SE. Dietary-fat-induced obesity in mice results in beta cell hyperplasia but not increased insulin release: evidence for specificity of impaired beta cell adaptation. D iabetologia 2005. 48(7):1350-1358.

3. Alonso LC, Yokoe T, Zhang P, Scott DK, Kim SK, O'Donnell CP, Garcia-Ocana A. Glucose infusion in mice: a new model to induce beta-cell replication. Diabetes 2007. 56:1792-1801.

4. Sorenson R L, Brelje TC. Adaptation of islets of Langerhans to pregnancy: beta-cell growth, enhanced insulin secretion and the role of lactogenic hormones. $\mathrm{H}$ orm $M$ etab R es 1997. 29:301-307.

5. Miettinen PJ, Ustinov J, Ormio P, Gao R, Palgi J, Hakonen $E$, Juntti-Berggren $L$, Berggren PO, Otonkoski T. D ownregulation of EGF receptor signaling in pancreatic islets causes diabetes due to impaired postnatal betacell grow th. D iabetes 2006. 55:3299-3308.

6. Dor Y, Brown J, Martinez OI, Melton DA. A dult pancreatic beta-cells are formed by self-duplication rather than stem- cell differentiation. $N$ ature 2004. 429:41-46.

7. Garcia-Ocana A, Takane KK, Syed MA, Philbrick WM, Vasavada RC, Stewart AF. H epatocyte growth factor overexpression in the islet of transgenic mice increases beta cell proliferation, enhances islet mass, and induces mild hypoglycemia. J Biol C hem 2000. 275(2):1226-1232.

8. Brelje TC, Parsons JA, Sorenson RL. R egulation of islet beta-cell proliferation by prolactin in rat islets. $D$ iabetes 1994. 43(2):263-273.

9. Tschen SI, Dhawan S, Gurlo T, Bhushan A. Agedependent decline in beta-cell proliferation restricts the capacity of beta-cell regeneration in mice. D iabetes 2009. 58(6):1312-1320.

10. Teta M, Long SY, Wartschow LM, Rankin MM, Kushner JA. V ery slow turnover of beta-cells in aged adult mice. D iabetes 2005. 54(9):2557-2567.

11. Cnop M, Hughes SJ, Igoillo-Esteve M, Hoppa MB, Sayyed F, van de Laar L, Gunter JH, de Koning EJ,
Walls GV, Gray DW, et al. The long lifespan and low turnover of human islet beta cells estimated by mathematical modeling of lipofuscin accumulation. Diabetologia 2010. 53(2):321-330.

12. Perl S, Kushner JA, Buchholz BA, Meeker AK, Stein GM, Hsieh M, Kirby M, Pechhold S, Liu EH, Harlan DM, Tisdale JF. Significant human beta-cell turnover is limited to the first three decades of life as determined by in vivo thymidine analog incorporation and radiocarbon dating. I C lin E ndocrinol M etab 2010. In press.

13. Butler AE, Janson J, Bonner-Weir S, Ritzel R, Rizza RA, Butler PC. Beta-cell deficit and increased beta-cell apoptosis in humans with type 2 diabetes. D iabetes 2003. 52(1):102-110.

14. Butler AE, Cao-Minh L, Galasso R, Rizza RA, Corradin $\mathbf{A}$, Cobelli $\mathbf{C}$, Butler $\mathbf{P C}$. A daptive changes in pancreatic beta cell fractional area and beta cell turnover in human pregnancy. D iabetologia 2010. In press.

15. Menge BA, Tannapfel A, Belyaev $\mathbf{O}$, Drescher $\mathbf{R}$, Müller C, Uhl W, Schmidt WE, Meier JJ. Partial pancreatectomy in adult humans does not provoke beta-cell regeneration. D iabetes 2008. 57:142-149.

16. Beattie GM, Itkin-Ansari P, Cirulli V, Leibowitz G, Lopez AD, Bossie S, Mally MI, Levine F, Hayek A. Sustained proliferation of PDX - 1+ cells derived from human islets. D iabetes 1999. 48(5):1013-1019.

17. Kayali AG, Flores LE, Lopez AD, Kutlu B, Baetge E, Kitamura R, Hao E, Beattie GM, Hayek A. Limited capacity of human adult islets expanded in vitro to redifferentiate into insulin-producing beta-cells. D iabetes 2007. 56(3):703-708.

18. Lefebvre VH, Otonkoski T, Ustinov J, Huotari MA, Pipeleers DG, Bouwens L. Culture of adult human islet preparations with hepatocyte growth factor and $804 \mathrm{G}$ matrix is mitogenic for duct cells but not for beta-cells. D iabetes 1998. 47(1):134- 137.

19. Fiaschi-Taesch NM, Salim F, Kleinberger J, Troxell R, Cozar-Castellano I, Selk K, Cherok E, Takane KK, Scott DK, Stewart AF. Induction of human beta-cell proliferation and engraftment using a single $\mathrm{G} 1 / \mathrm{S}$ regulatory molecule, cdk6. D iabetes 2010. 59(8):1926-1936.

20. Meier JJ, Bhushan A, Butler AE, Rizza RA, Butler 
PC. Sustained beta cell apoptosis in patients with longstanding type 1 diabetes: indirect evidence for islet regeneration? D iabetologia 2005. 48(11):2221-2228.

21. Houbracken I, Bouwens L. The quest for tissue stem cells in the pancreas and other organs and their application in beta-cell replacement. R ev D iabet Stud 2010. 7(2):112-123. This issue.

22. Lardon J, Huyens N, Rooman I, Bouwens L. Exocrine cell transdifferentiation in dexamethasone-treated rat pancreas. V irchows A rch 2004. 444:61-65.

23. Suzuki T, Kadoya Y, Sato Y, Handa K, T akahashi T, Kakita A, Yamashina S. The expression of pancreatic endocrine markers in centroacinar cells of the normal and regenerating rat pancreas: their possible transformation to endocrine cells. A rch H istol C ytol 2003. 66:347-358.

24. X u X, D'Hoker J, Stange G, Bonne S, De Leu N, Xiao X, Van de Casteele M, Mellitzer G, Ling $Z$, Pipeleers $\mathbf{D}$, et al. Beta cells can be generated from endogenous progenitors in injured adult mouse pancreas. $\mathrm{C} \mathrm{ell}$ 2008. 132(2):197-207.

25. Guz Y, Nasir I, Teitelman G. R egeneration of pancreatic beta cells from intra-islet precursor cells in an experimental model of diabetes. Endocrinology 2001. 42:4956-4968.

26. Z hou Q, Brown J, Kanarek A, Rajagopal J, Melton DA. In vivo reprogramming of adult pancreatic exocrine cells to beta-cells. N ature 2008. 455:627-632.

27. Gu D, Sarvetnick N. Epithelial cell proliferation and islet neogenesis in IFN-gamma transgenic mice. D evelopment 1993. 118(1):33-46.

28. Wang RN, Klöppel G, Bouwens L. Duct- to islet-cell differentiation and islet growth in the pancreas of ductligated adult rats. D iabetologia 1995. 38(12):1405-1411.

29. R osenberg $\mathbf{L}$. Induction of islet cell neogenesis in the adult pancreas: the partial duct obstruction model. M icrosc $R$ es $T$ ech 1998. 43(4):337-346.

30. Inada A, Nienaber C, Katsuta H, Fujitani Y, Levine J, Morita R, Sharma A, Bonner-Weir S. C arbonic anhydrase II-positive pancreatic cells are progenitors for both endocrine and exocrine pancreas after birth. P roc N atl A cad Sc U SA 2008. 105(50):19915-19919.

31. Phillips JM, O'R eilly L, Bland C, Foulis AK, Cooke A. Patients with chronic pancreatitis have islet progenitor cells in their ducts, but reversal of overt diabetes in NOD mice by anti-CD 3 shows no evidence for islet regeneration. D iabetes 2007. 56(3):634-640.

32. Martin-Pagola A, Sisino G, Allende G, DominguezBendala J, Gianani R, Reijonen H, Nepom GT, Ricordi C, Ruiz P, Sageshima J, et al. Insulin protein and proliferation in ductal cells in the transplanted pancreas of patients with type 1 diabetes and recurrence of autoimmunity. D iabetologia 2008. 51(10):1803-1813

33. Hao E, Tyrberg B, Itkin-Ansari P, Lakey JR, Geron I, Monosov EZ, Barcova M, Mercola M, Levine F. Bcell differentiation from nonendocrine epithelial cells of the adult human pancreas. $\mathrm{N}$ at $\mathrm{M}$ ed 2006. 12(3):310-316

34. Solar M, Cardalda C, Houbracken I, Martin M, Maestro MA, De Medts N, Xu X, Grau V, Heimberg H, Bouwens L, Ferrer J. Pancreatic exocrine duct cells give rise to insulin-producing beta cells during embryogenesis but not after birth. D ev C ell 2009. 17(6):849-860.

35. Chung CH, Hao E, Piran R, Keinan E, Levine F. Pancreatic beta cell neogenesis by direct conversion from mature al pha-cells. Stem C ells 2010. In press.
36. Herrera PL. Adult insulin- and glucagon-producing cells differentiate from two independent cell lineages. D evelopment 2000. 127(11):2317-2322.

37. Collombat $\mathbf{P}, \mathbf{X} \mathbf{u} \mathbf{X}, \mathbf{R}$ avassard $\mathbf{P}$, Sosa-Pineda $\mathbf{B}$, Dussaud S, Billestrup N, Madsen OD, Serup P, Heimberg $\mathbf{H}$, Mansouri A. The ectopic expression of Pax4 in the mouse pancreas converts progenitor cells into alpha and subsequently beta cells. C ell 2009. 138(3):449-462.

38. Thorel F, Nepote V, Avril I, Kohno K, Desgraz R, Chera S, Herrera PL. Conversion of adult pancreatic alpha-cells to beta-cells after extreme beta-cell loss. $\mathrm{N}$ ature 2010. 464(7292):1149-1154.

39. Hirata Y, Uchihashi M, Nakajima M, Fujita T, Matsukura S. Immunoreactive human epidermal growth factor in human pancreatic juice. J C lin Endocinol M etab 1982. 54(6):1242-1245.

40. Chaurasia OP, Marcuard SP, Seidel ER. Insulin-like growth factor I in human gastrointestinal exocrine secretions. R egul Pept 1994. 50(2):113-119.

41. Klöppel G, Detlefsen S, Feyerabend B. Fibrosis of the pancreas: the initial tissue damage and the resulting pattern. V irchows A rch 2004. 445(1):1-8.

42. Yasuda H, Kataoka K, Ichimura H, Mitsuyoshi $\mathbf{M}$, Iida T, Kita M, Imanishi J. Cytokine expression and induction of acinar cell apoptosis after pancreatic duct ligation in mice. J Interferon C ytokine R es 1999. 19(6):637-644.

43. Bhatia M, Brady M, Shokuhi S, Christmas S, Neoptolemos JP, Slavin J. Inflammatory mediators in acute pancreatitis. J Pathol 2000. 190(2):117-125.

44. Steinle AU, Weidenbach H, Wagner M, Adler G, Schmid RM. N F-kappaB/R el activation in cerulein pancreatitis. $G$ astroenterology 1999. 116(2):420- 430.

45. Vaquero E, Gukovsky I, Zaninovic V, Gukovskaya AS, Pandol SJ. Localized pancreatic N F-kappaB activation and inflammatory response in taurocholate-induced pancreatitis. Am J Physiol Gastrointest Liver Physiol 2001. 280(6):G 1197-G1208.

46. Lenzen S. The mechanisms of alloxan- and streptozotocininduced diabetes. D iabetologia 2008. 51(2):216-226.

47. Gromada J, Franklin I, Wollheim CB. Alpha-cells of the endocrine pancreas: 35 years of research but the enigma remains. Endoor R ev 2007. 28(1):84-116.

48. Kawamori D, Kurpad AJ, Hu J, Liew CW, Shih JL, Ford EL, Herrera PL, Polonsky KS, McGuinness OP, Kulkarni RN. Insulin signaling in alpha cells modulates glucagon secretion in vivo. C ell M etab 2009. 9(4):350-361.

49. Bosco D, Armanet M, Morel P, Niclauss N, Sgroi A, Muller YD, Giovannoni L, Parnaud G, Berney T. U nique arrangement of alpha and beta-cells in human islets of Langerhans. D iabetes 2010. 59(5):1202-1210.

50. Nir T, Melton DA, Dor Y. R ecovery from diabetes in mice by beta cell regeneration. I C lin Invest 2007. 117(9):2553-2561.

51. Yoon KH, Ko SH, Cho JH, Lee JM, Ahn YB, Song KH, Y oo SJ, Kang MI, Cha BY, Lee KW, et al. Selective beta-cell loss and alpha-cell expansion in patients with type 2 diabetes mellitus in Korea. J C lin E ndocinol M etab 2003. 88(5):2300-2308.

52. Gelling RW, Du XQ, Dichmann DS, Romer J, H uang $\mathrm{H}, \mathrm{C}$ ui L, O bici S, T ang B, Holst J, Fledelius C, et al. Lower blood glucose, hyperglucagonemia, and pancreatic alpha cell hyperplasia in glucagon receptor knockout mice. Proc N atl A cad Sci U SA 2003. 100(3):1438- 
1443.

53. Vierbuchen $\mathbf{T}$, Ostermeier A, Pang ZP, Kokubu $\mathbf{Y}$, Südhof TC, Wernig M. Direct conversion of fibroblasts to functional neurons by defined factors. N ature 2010. 463:1035-1041.

54. Slack JM. Metaplasia and transdifferentiation: from pure biology to the clinic. $\mathrm{N}$ at R ev M ol C ell Biol 2007. 8(5):369-
378.

Special Issue

Wang AY, Ehrhardt A, Xu H, Kay MA. Adenovirus transduction is required for the correction of diabetes using Pdx-1 or Neurogenin-3 in the liver. Mol Ther 2007. 15(2):255-263.

56. Z aret KS, White MF. Diabetes forum: extreme makeover of pancreatic alpha cells. N ature 2010. 464(7292):1132-1133. 